\title{
KEKUATAN GENGGAMAN TANGAN PADA PASIEN POST STROKE
}

\author{
Hand Grip Strength Of Post Stroke Patient
}

\section{Rumentalia Sulistini I ${ }^{\text {* }}$ \\ Musonathul Khasifah $\mathbf{2}^{2}$ \\ Hanna DL Damanik $3^{3}$ \\ Jurusan Keperawatan \\ Poltekkes Palembang, \\ Palembang, Sumatera Selatan , Indonesia \\ 2Prodi D-IV keperawatan \\ Poltekkes Palembang \\ ,Palembang, Sumatera Selatan \\ Indonesia \\ 3Jurusan Keperawatan, \\ Poltekkes Palembang, \\ Palembang, Sumatera Selatan, \\ Indonesia \\ *email: \\ rumentaliasulistini@gmail.com}

\section{Kata Kunci:}

Stroke

Kekuatan

Genggaman tangan

\section{Keywords:}

Stroke

Strength

Hand grip

\begin{abstract}
Abstrak
Stroke adalah kehilangan fungsi otak yang diakibatakan oleh berhentinya suplai darah sebagian otak. Kematian jaringan otak akibat stroke dapat menyebabkan kelemahan otot pada bagian anggota gerak tubuh yang terkena seperti jari-jari tangan. Kondisi ini mempengaruhi kemampuan beraktivitas dan kualitas hidup pasien Pasien tidak hanya mengalami kelumpuhan tetapi juga mengalami gangguan kognisi, gangguan komunikasi dan gangguan lapang pandang atau defisit dalam persepsi. Penelitan ini bertujuan mengetahui kekuatan genggam tangan penderita post stroke. Usia responden rata - rata 60,5 tahun dengan usia termuda 41 tahun dan 80 tahun usia tertua. Rata -rata kekuatan genggaman tangan 7,4 kg dengan kekuatan terendah I,3 $\mathrm{kg}$ dan tertinggi $18,6 \mathrm{~kg}$. Didapatkan ada hubungan usia dengan kekuatan otot pasca stroke ( $\mathrm{p} 0,023$ ). Hubungan usia dengan kekuatan otot pasca Stroke menunjukan hubungan yang kekuatan sedang dengan berpola negatif artinya semakin bertambah umur maka kekuatan otot berkurang. Sehingga perlu dikembangkannya Pola Aktivitas dan latihan bagi pendertia Post Stroke di Rumah Sakit maupun Masyarakat.
\end{abstract}

\begin{abstract}
Stroke is a loss of brain function caused by the cessation of blood supply in part of the brain. Death of brain tissue due to stroke can cause muscle weakness in the affected limb such as fingers. This condition affects the ability to move and the quality of life of patients. Patients not only experience paralysis but also experience cognitive impairment, communication disorders and visual field disorders or deficits in perception. Aims this study was to describe hand grip strength The average age of respondents was 60.5 years with the youngest age 41 years and 80 years of age. The average strength of hand grip is 7.4 $\mathrm{kg}$ with the lowest strength is $1.3 \mathrm{~kg}$ and the highest is $18.6 \mathrm{~kg}$. Obtained a relationship between age and muscle strength after stroke ( $p$ 0.023). The relationship between age and post-stroke muscle strength shows that the relationship between medium strength and negative patterning means that as you age, muscle strength decreases. So it is necessary to develop the Pattern of Activities and exercises for Post Stroke in Hospitals and the Community.
\end{abstract}

(C) year The Authors. Published by Institute for Research and Community Services Universitas Muhammadiyah Palangkaraya. This is Open Access article under the CC-BY-SA License (http://creativecommons.org/licenses/by-sa/4.0/). DOI: https://doi.org//0.33084/jsm.vxix.xxx.

\section{PENDAHULUAN}

Stroke adalah kehilangan fungsi otak yang diakibatakan oleh berhentinya suplai darah sebagian otak ( Smelzer dan Bare, 2008). Stroke merupakan istilah yang digunakan untuk mendeskipsikan gangguan neurologis yang disebabkan terputusnya aliran darah ke sebagian otak ( Black \& Hawks, 2009)
Prevalensi stroke di Indonesia sebesar 10,9 permil (Kemmenkes, 2018) mengalami penurunan dibangingkan dengan data Riset Kesehatan Dasar pada tahun 2013 yaitu sebesar 12,I permil,. Sedangkan pembiayaan untuk pelayanan kesehatan penderita stroke terus meningkat. Faktor risiko stroke seperti, tekanan darah tinggi, diabetes, obesitas, kolesterol tinggi, penyakit jantung bawaan, merokok mengalami peningkatan ( Kemenkes, 2018 ). Faktor risiko ini 
menyebabkan terjadi kejadian stroke hemoragie maupu non hemoragie. Stroke hemoragie terjadi perdarahan serebral atau subraknoid yang disebabkan oleh pecahnya pembuluh darah otak, Sedangkan stroke non hemoragi (iskemik) tersumbatnya pembuluh darah yang menyebabkan aliran darah ke otak sebagian atau keseluruhan terhenti. Sebagian besar orang mengalami stroke non hemoragi (80-85\%) (Goldszmidt \& Caplan, 20I3). Sebagian besar pasien stroke non hemoragi (iskemik) yang hidup mengalami kecacatan fisik karena defisit neurologis yang menetap. Pasien tidak hanya mengalami kelumpuhan tetapi juga mengalami gangguan kognisi, gangguan komunikasi dan gangguan lapang pandang atau defisit dalam persepsi (AHA, 2010). Kematian jaringan otak akibat stroke dapat menyebabkan kelemahan otot pada bagian anggota gerak tubuh yang terkena seperti jari-jari tangan (Prok, Gessal \& Angliadi , 2016). Kondisi ini mempengaruhi kemampuan beraktivitas dan kualitas hidup pasien.

Kekuatan otot pada anggota gerak termasuk didalamnya kekuatan Genggaman tangan. Kekuatan ini dapat dideteksi dengan menngunakan Hand Grip dyanamometer yang didesain menekankan pada efektifitas kerja otot tangan ( Anditmika \& Santika, 2015). Kekuatan Genggaman tangan dihitung dengan satuan kilogram. Kekuatan genggaman tangan pada Pria dan Wanita memiliki Perbedaan dan terdapat pula perbedaan antara lengan kanan dan kiri. Untuk tangan kanan pada untuk Pria kiteria baik 46,5 - $55 \mathrm{~kg}$ dan 32,5 - $41 \mathrm{~kg}$ pada perempuan, sedangkan kriteria baik untuk tangan kiri 44.5 -54 pada laki laki dan 27 - 36,5 pada wanita (Anditmika \& Santika, 20I5). Untuk itu perlu dilakukannya identifikasi kekuatan gengaman tangan pada pasien post stroke, sehingga dapat memonitor perkembangan motorik pasien sebelum atau setelah dilakukan intervesi selama pasien di Rumah sakit.

\section{METODOLOGI}

Penelitian ini merupakan survey analitik dengan desain cross sectional. Responden Penelitian berjumlah 34 responden dengan kriteria inklusi responden yang pertama kali melakukan fisioterapi. Kriteria eksklusi untuk responden yang mengalami fraktur pada ekstremitas atas. Pengambilan sampel dilakukan dengan non random sampling. Penelitian di lakukan di Unit fisioterapi. Instrumen penelitian menggunakan kuesioner dan lembar observasi. Pengukuran genggaman tangan dilakukan menggunakan handgrip dynamometer tipe EHIOI. Pengukuran dilakukan sebelum responden melakukan fisioterapi.

\section{HASIL DAN PEMBAHASAN}

Penelitian ini mengambarkan hasil analisis dari data yang diambil pada responden postsroke. Karakteristik responden pada penelitian ini berdasarkan jenis kelamin tingkat pendidikan dan usia.

Tabel I. Distribusi frekuensi karakteristik Responden (n 32)

\begin{tabular}{lcc}
\hline Karakteristik & $\mathbf{n}$ & Persentasi (\%) \\
\hline Jenis Kelamin & & \\
Laki - laki & 14 & 41.2 \\
Perempuan & 20 & 58.8 \\
Pendidikan & & \\
SD & $1 \mathrm{I}$ & 32.2 \\
SMP & 10 & 29.4 \\
SMA & 10 & 29.4 \\
Sarjana & 3 & 8.8 \\
\end{tabular}

Responden perempuan lebih banyak (58,8\%) dan pendidikan terbanyak SD (32,2\%).

Tabel II. Distribusi responden berdasarkan Usia dan kekuatan genggaman tangan (n 32)

\begin{tabular}{lccccc}
\hline Variabel & $\begin{array}{c}\text { Mea } \\
\mathbf{n}\end{array}$ & $\begin{array}{c}\text { Med } \\
\text { ian }\end{array}$ & SD & $\begin{array}{c}\text { Min- } \\
\text { Max }\end{array}$ & $\mathbf{9 5 \%} \mathbf{C l}$ \\
\hline Usia & 60.67 & 60.50 & 8.003 & $4 I-80$ & $57.8-63.4$ \\
& & & & & \\
\hline $\begin{array}{l}\text { Kekuatan } \\
\text { gengaman } \\
\text { tanggan }\end{array}$ & 7,4 & 8,2 & 4,87 & $1,3-$ & $5,74-$ \\
\hline
\end{tabular}

Usia responden rata - rata 60,5 tahun dengan usia termuda $4 \mathrm{I}$ tahun dan 80 tahun usia tertua. Rata -rata kekuatan genggaman tangan 7,4 kg dengan kekuatan terendah I,3 kg dan tertinggi 18,6 kg. 
Tabel III. Kekuatan gengaman tangan bersarkan usia pasien pasca stroke

\begin{tabular}{ccc}
\hline Variabel & $\mathbf{r}$ & P Value \\
\hline Kekuatan otot & $-0,389$ & 0.023 \\
Usia & & \\
& & \\
\hline
\end{tabular}

Tabel III. memperlihatkan ada hubungan usia dengan kekuatan otot pasca Stroke ( $P$ value 0.023) dan menunjukan hubungan kekuatan sedang berpola negatif artinya semakin bertambah umur maka kekuatan otot berkurang.

Kekuatan genggam jari pada pasien post stroke menunjukan rata rata $7,4 \mathrm{~kg}$. hal ini mengambarkan bahwa kekuatan genggaman jari pada pasien post stroke masuk dalam kriteria kurang sekali yaitu $\leq 13,5 \mathrm{~kg}$ (Anditmika \& S Santika, 20I5). Soohee \& Joo-Young (2016) berpendapat bahwa kekuatan genggaman tangan sisi yang tidak terpengaruh pada pasien dengan hemiplegi lebih rendah daripada orang tanpa hemiplegia. Pada pasien hemiplegi akan terjadi masalah pada kedua tangan. Sehingga dapat disimpulkan bahwa kelemahan otot terjadi pada sisi yang terkena maupun yang tidak pada pasien pasca stroke. Oleh karena itu intervensi keperawatan untuk meningkatkan kemampuan otot tangan seperti Range of Motion (ROM) dilakukan pada kedua sisi lengan.

Usia pasien post stroke pada penelitian ini diapatkan rata - rata berusia 60,67 tahun dengan usia tertua 80 tahun. Korelasi usia dengan kekuatan genggam tangan menunjukan hubungan yang signifikan dan memperlihatkan semakin tua maka kekuatan otot tangan semakin menurun ( $r$-0,389). Risiko Stroke meningkat dengan pertambahan usia, hal ini dapat dijelaskan bahwa pada proses penuaan tubuh mengalami kemunduran fungsi.

Menurut Sions et. al (2012) menyatakan ada hubungan langsung antara kekuatan otot dan penambahan usia, yaitu pada usia 65 - 80 tahun akan mengalami penurunan kemampuan isokinetik ekstensi lutut. Dan pada penderita stroke juga mengalami penurunan jumlah serat Tipe II yang menyebabakan kehilangan kekuatan otot. Selain itu penderita akan manealami atropi otot dan menurunnya ukuran otot.

Untuk itu perlu adanya upaya dalam meminimalkan kecacatan atau komplikasi setelah serangan stroke. Sepuluh proritas yang perlu menjadi perhatian tenaga kesehatan dalam merawat pasien stroke adalah (I) kognitif (2) Aphasia (3) Pengelihatan (4) Perbaikan fungsi Lengan (5) Fatigue (6) keseimbangan (7) Mobilitas (8) meningkatkan Percaya diri (9) meningkatkan fungsi ( 10 ) Kualitas hidup dan menghindari stroke berulang (Saunder, Greig \& Mead , 20I4). Perbaikan fungsi lengan pada pasien dengan post stroke dapat dilakukan dengan terapi aktif diantaranya latihan Rentang Gerak, latihan Penguatan dan latihan menggengam bola. Prok, Gessal \& Angliadi (2016) memperlihatkan pengaruh yang sifnifikan pada penggunaan latihan gerak aktif menggengam boa pada pasien stroke. Menurut Stock et.al ( 2019) kekuatan tangan akibat stroke dapat mengalami perbaikan jika dilakukan tidak lanjut selama I tahun atau 6 bulan pertama. Untuk itu tenaga kesehatan perlu memahami penanganan tersebut sehingga kualitas hidup pasien Stroke dapat meningkat.

\section{KESIMPULAN}

Kekuatan gengaman tangan pada penderita post stroke termasuk dalam kriteria kurang sekali ( $<13,5 \mathrm{Kg}$ ). ada hubungan usia dengan kekuatan otot pasca Stroke ( P value 0.023) dan semakin bertambah umur maka kekuatan otot berkurang. Perlu dilakukan perbaikan fungsi lengan dengan berbagai metode diantaranya latihan rentang gerak, latihan penguatan dan latihan gengam bola selama di Rumah maupun Rumah Sakit. Peneliti selanjutnya dapat melakukan uji coba pada intervensi tersebut untuk melihat pengaruhnya bagi peningkatan kekuatan otot pasien. 


\section{UCAPAN TERIMA KASIH}

Ucapan terima kasih kepada seluruh sivitas akademika yang telah membantu dalam proses Penelitian. Enumerator Penelitian yang meluangkan waktu dalam pengumpulan data. Instansi Rumah sakit sebagai tempat penelitian yang telah memberikan kesempatan.

\section{REFERENSI}

I. Aditmika \& Santika. 20I5. Tes dan pengukuran jasmani \& Olahraga. Solo : TB Rahma

2. American Heart Association (AHA). 2010. Adult Basic Life Support : Guidelines for CPR and Emergency Cardiovascular Care, http://circ.ahajournals.org/content//22//8_suppl_ 3/S685

3. Black, M. J \& Hawks, H. J. 2009. Medical Surgical Nursing : Clinical management for Continuitu of Care, 8th ed. Philadelphia : WB Sounders Company.

4. Goldszmidt A J \& Caplan LR .2013. Stroke Essential Vol 2. PT Indeks

5. Kemenkes . 2018. Hasil utama Riset Kesehatan Dasar. Jakarta. Jakarta. Badan penelitian dan pengembangan Kesehatan Kementerian Kesehatan.

6. Prog W, Gessal J, Angliadi .2016. Pengaruh Latihan Gerakan Aktif menggenggam Bola pada Pasien Stroke di Ukur menggunakan Handgrip Dynamometer. Jurnal E-Clinic. Vol 4 (I) : 7 I - 75

7. Sions, J.M. Tyrell CM, Knarr BA, Jancosko A, Binder-Macleod SA, 20I2. Age and Stroke Related Skeletal Muscle Changes : A Review for The Geriatric Clinician. Journal Geriatr Phys Ther. 35 (3) : |55-|6|

8. Saunder, D.H, Greig CA, Mead GE .2014. Physical Activity and Exercises After Stroke Review of Multiple Meanigful benefits. Stroke American Hearth Association. 45 ( I2) : 3742 -374I
9. Smelzer SC \& Bare BG . 2008. Buku Ajar kesehatan Medikal Bedah, Volume 2, Edisi 8 jakarta. Buku Kedokteran EGC.

10. Soohee \& Joo-Young ( 2016) Grip Strength in post Stroke hemiplegia. The Journal of Physical Therapy Science 28 : 677-679

I I. Stock R., Thrane G., Askim T., Ankle A, Mork PJ., 2019. Development of Grip Strength During The First year After Stroke. Jurnal Rehabilitation Medicine 5 I (I-9) 